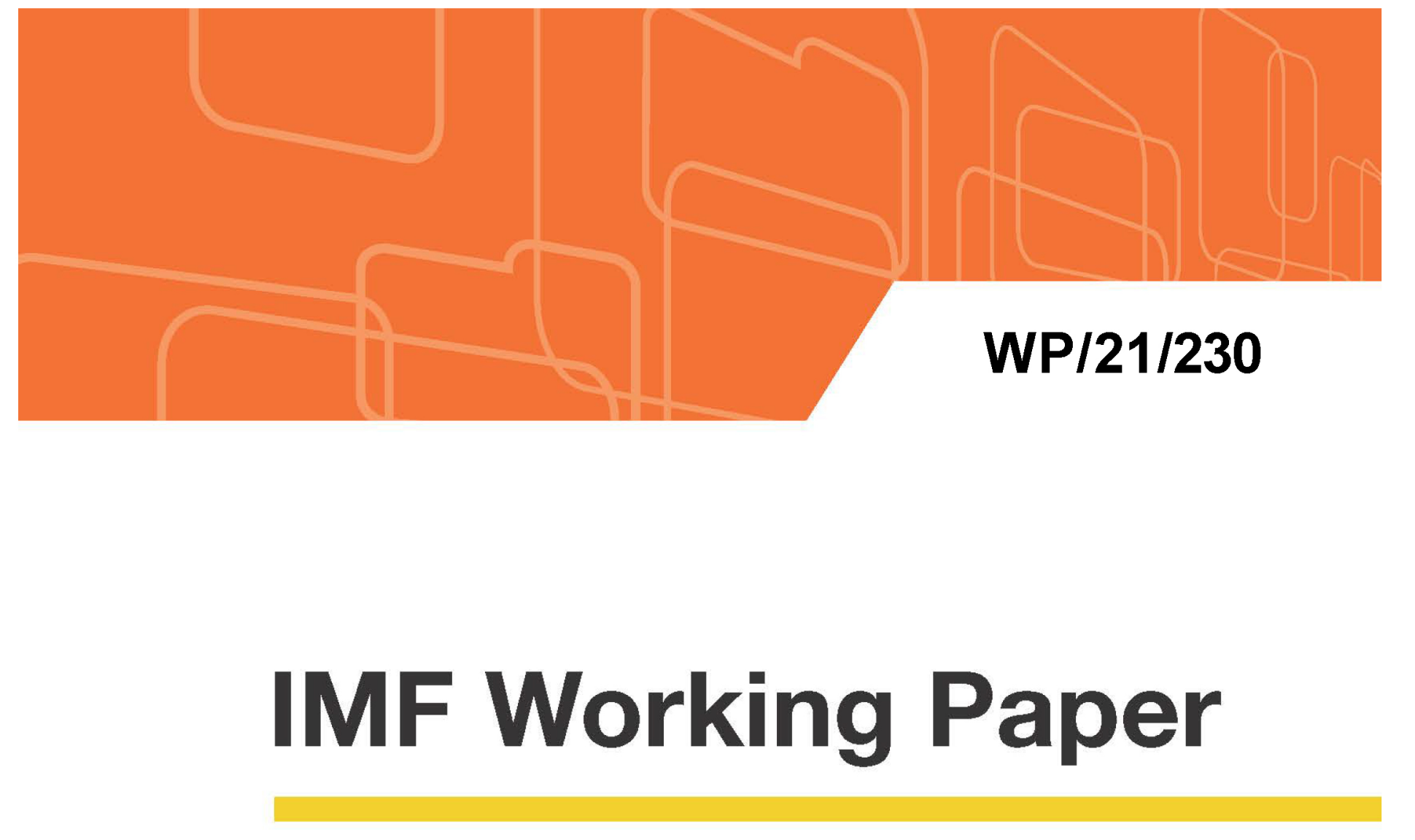

\title{
Optimal State Contingent Sovereign Debt Instruments
}

\author{
by Alejandro D. Guerson
}

IMF Working Papers describe research in progress by the author(s) and are published to elicit comments and to encourage debate. The views expressed in IMF Working Papers are those of the author(s) and do not necessarily represent the views of the IMF, its Executive Board, or IMF management. 


\title{
IMF Working Paper
}

Western Hemisphere Department

\section{Optimal State Contingent Sovereign Debt Instruments}

\author{
Prepared by Alejandro D. Guerson
}

Authorized for distribution by Sònia Muñoz

September 2021

\section{IMF Working Papers describe research in progress by the author(s) and are published to elicit comments and to encourage debate. The views expressed in IMF Working Papers are those of the author(s) and do not necessarily represent the views of the IMF, its Executive Board, or IMF management.}

\begin{abstract}
This paper shows that the optimal sovereign lending contract is state-contingent when a government can default. It provides a theoretical basis for the specification of optimal statecontingent debt instruments (SCDIs) in countries subject to large shocks that can be observed and verified by all parties involved, such as natural disasters or global pandemics. The result is obtained as the endogenous solution to a contracting problem under time-inconsistency when a government cannot credibly commit to honor debt service obligations in all possible states of nature. It is shown that rational investors optimally offer SCDIs that include additional financing when the default constraint is binding, keeping the debtor engaged in the contractual relationship and avoiding asset loss. The debtor benefits because the contract implies net-positive financing when facing a large shock, increasing concurrent welfare, while maintaining access to financing in the future for consumption smoothing at the same terms as with precommitment. SCDIs require maintaining debt at a low level compared to the precommitment case, and also a fiscal consolidation when triggered to contain the increase in debt. Extension of the time inconsistency problem to add the taxation of capital returns shows that the optimal physical capital investment is also state-contingent.
\end{abstract}

JEL Classification Numbers: F34, F41, H63.

Keywords: sovereign default; natural disasters; state-contingent debt.

Author's E-Mail Address: aguerson@,imf.org 
I. INTRODUCTION AND BACKGROUND ____________________________________________________________ 4

II. THE ECONOMY_________________________________________________________________

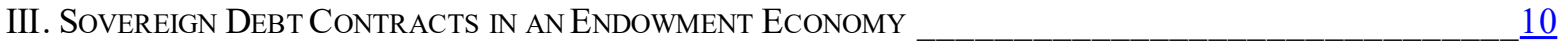

IV. Sovereign Debt Contracts in An ECONOMy with Production _____________________

V. CONCLUSION__________________________________________________________________________

VI. REFERENCES _______________________________________________________________________ 


\section{INTRODUCTION AND BACKGROUND}

State-contingent debt instruments (SCDIs) have been studied and utilized for some time as a way to provide debt service relief to creditors in bad times and to align debt service with payment capacity, reducing the probability of a default. In debt restructuring negotiations, SCDIs have been used to facilitate critical mass creditor participation, helping ease creditor coordination and ameliorating the free rider problem. If SCDIs account for a significant share of public debt, they can reduce the incidence and cost of sovereign debt crises. Also, by linking debt service to a measure of the sovereign's capacity to pay, SCDIs can broaden the sovereign's investor base and open opportunities for risk diversification, ultimately enhancing the resilience of the international financial system.

A strand of the SCDIs literature has focused on facilitating creditor-borrower agreement in sovereign debt restructurings. An early bunch of SCDIs proposals arised in the context of the oil crisis in the $1980 \mathrm{~s}^{1}$ that led to a number of sovereign restructurings worldwide. For example, Bailey (1983) suggested the conversion of debt into proportional claims on exports. Krugman (1988) and Froot, Scharfstein, and Stein (1989) considered the relative merits of indexing debt to variables out of the debtor country's control (such as commodity prices) versus variables partially under the country's control (exports or GDP). Besley and Powell (1989) argued that commodity price indexation is optimal from a creditor's perspective because it allows risk sharing, reducing the probability of default. Shiller (1993) proposed the creation of "macro markets" for GDP-linked securities, in the form of perpetual claims on a fraction of a country's GDP.

SCDIs have been reexamined in the early 2000 s to facilitate debt restructurings in the context of an increase in global financial integration since the 1990s and the proliferation of sudden stops in capital flows (Calvo 1998) - that is, external adjustments with capital and financial account reversals that followed the Asian crisis in 1997 and the Russian crisis in 1998. More recently, the 2007 global financial crisis led to financial and external sector pressures globally. Tightening of global financial conditions increased global interest rates, curtailed access to public and private financing, and ignited capital outflows, increase of sovereign spreads, and led to exchange rate depreciation, financial sector pressures, and in several cases to sovereign debt restructurings. ${ }^{2}$ In this context, uncertainty with regards sovereign debt service capacity led to the reconsideration of SCDIs with procyclical upside/downside indexation to future growth and/or the state of the cycle. For example, Borenztein and Mauro (2002) analyzed GDP-linked bonds to reduce the probability of explosive debt paths. Braun and Tomassi (2003) proposed the introduction of bonds with interest payments indexed to variables representative of the state of the cycle or the ability to generate surpluses to service debt, such as GDP or exports. Kim and Ostry (2018) argued that GDP-linked bonds can help create fiscal space and

\footnotetext{
${ }^{1}$ See for example Dooley (1986).

${ }^{2}$ GDP-linked warra nts have been introduced in the debt restructurings in Argentina (2005), Greece (2012), and Ukraine (2015).
} 
support debt sustainability in a context of stagnation and monetary policy constrained at the zero-lower-bound. ${ }^{3}$

SCDIs have also been issued in sovereign debt restructurings to provide financial relief in case of natural disasters, including parametric triggers linked to natural hazards. ${ }^{4}$ For example, Mallucci (2020) evaluated the debt and welfare impact of introducing SCDIs in government bonds in countries affected by large natural disasters. He calibrated a model to a sample of Caribbean economies and showed that SCDIs improve welfare, allowing countries to carry additional debt because the risk of default is reduced.

More recently, SCDIs have also been considered to address debt sustainability concerns for highly indebted countries, considering that reduction of public debt ratios from high levels with growth and fiscal consolidation can take a long time. Carnot and Pamies-Sumner (2017) simulate GDP-linked SCDIs for a sample of European Countries and showcase their debtstabilization benefit. Fournier and Lehr (2018) add the creditor perspective and analyze the default risk premia of GDP-linked SCDIs implied by the Capital Asset pricing Model and argue the risk premium investors would demand to compensate for growth risks is lower than "acceptable" risk premium for governments, suggesting there could be a market for SCDIs. These studies also emphasize the value that issuance SCDIs can have at all times, as opposed to just in debt restructurings.

The existing literature, however, analyzes the merits of SCDIs in an ad-hoc fashion, without a specific formal derivation to assess their optimality and specific form. This paper bridges this gap: a specific form of SCDIs emerges optimaly from a contracting sovereign lending problem. The result is obtained from an Eaton-Gersovitz $(1981)^{5}$ economy with sovereign default, solving the problem from the investor vintage explicitly - the borrower can repudiate debt at the cost of becoming permanetly excluded from financial markets, moving to financial autarchy. To this end, the set up proposed in this paper lifts the pre-commitment assumption on sovereign debt issuance used in standard macroeconomic models, resulting in time inconsistency on debt issuance and the possibility of sovereign default. It is shown that the internalization of this possibility by investors results in state-contingent debt as the optimal solution to the contracting problem.

Lifting of the precommittment technology assumption, however, implies that the standard recursive formulation to derive an equilibrium is not applicable: the default constraint spans the entire future and as a result the equilibrium cannot be characterized by state-invariant

\footnotetext{
${ }^{3}$ Other examples in the litera ture include Bla nchard, Mauro, and Acalin, (2016); Bowman and Naylor (2016); Brooke, Pienkowski, and Santor (2013); Cabrillac, Ga uvin, and Gossé(2017); Cecchetti and Schoenholtz (2017); Consiglio and Zenios (2015); Makoff (2017); Neftciand Santos (2003).

${ }^{4}$ Barbados and Grenada a rerecent examples of introduction of natural disa ster clauses in sovereign bonds issued in debt restructuring. International financial institutions have a lso supported the use of SCDIs. See International Monetary Fund $(2004,2011,2016)$.

${ }^{5}$ See also Eaton, Gersovitz and Stiglitz J. (1986); Grossman H. and Van Huyck J. (1988); Cohen and Sachs (1986); Cole and Kehoe (1995); Eaton (1990).
} 
optimal decision rules. A solution to this type of problems can be obtained by introducing recursive multipliers proposed in Marcet and Marimon (2019) ${ }^{6}$ which keep track of the entire history of past episodes in which the default participation constraint bind.

The resulting equilibrium conditions show that, when the participation constraint bind and the sovereign borrower has incentives to default, the slope of the borrowers' optimal lending decision rules change. The characterization of the lending equilibrium conditions for an endowment economy imply that the optimal contract is state-contingent and has the following specific form:

- State-contingent debt contracts are optimal from a creditor welfare perspective provided the sovereign has no commitment technology on the promise of "no default", that is, when the time inconsistency problem is present.

- Issuance of SCDIs is optimal at all times, and not just in periods in which participation constraint bind.

- The optimal contract specifies net-positive financing when the default constraint binds. This keeps the sovereign debtor engaged in the lending agreement and eliminates the creditor's asset loss.

- There is no default in equilibrium. As a result, there is no risk premia and the sovereign's borrowing interest rates remain at the international "risk-free" level.

- The borrowing sovereign economy issues debt and achieves "full insurance" in normal times when output shocks are relativelly small and the debt stock is small enough such that the participation constraint is not binding.

- $\quad$ Changes in variables representative of the state of the cycle, or affecting debt servicing capacity, do not affect debt service commitments or interest rates in normal times when the participation or default constraint does not bind.

- When the participatipon constraint binds, the contract requires the sovereign borrower to do a fiscal consolidation, resulting in "partial insurance". Financing is limitted to a level that is just enough to keep the borrower engaged in the contractual debt agreement.

- Because the default constraint may bind in the future, triggering net-positive financing, the soveregin debtor is required to have low levels of debt compared to the case of full commitment.

\footnotetext{
${ }^{6}$ Other studies of equilibria under limited enforcement and absence of commitment technology include Chari and Kehoe (1989); Kehoea nd Perri (2002); Kletzer and Wright (2000); Kocherlakota (1996).
} 
The analysis is then extended to an economy with production and capital investment. As a result, the lack of commitment technology and time inconsistency problem is extended to the taxation of capital returns (Kydland and Prescott, 1977). Notice that this is a natural assumption: if a government cannot commit to the promise of "no default" then there is no reason to assume it can commit to other promises such as the capital return tax rate. ${ }^{7}$ Investors would then also internalize the possibility of a deviation from the announced tax rate in bad states as the government intends to cushion the concurrent loss of welfare. The results indicate that:

- Equilibrium investment and output are lower than in an economy with precommitment.

- With capital return taxation, the optimal contract includes an additional capital investment condition that implies that the optimal capital investment is also statecontingent. During bad states such that the participation constraint binds, it requires additional investment to keep the sovereign engaged in the contractual relationship.

The paper is organized in four additional sections. Section II presents the general economy setup. Section III characterizes the solution under participation constraints, and derives a optimal public debt contract for an endowment economy. Section IV extends the contract to the case of an economy with production and investment. Section $V$ concludes.

\section{THE ECONOMY}

Consider an economy inhabited by a large class of identical individuals. Every period, each individual's level of consumption $g_{t}$ is determined by a transfer from the government. These individuals can be regarded as being "poor", and depend on a transfer from the government to survive. Agents have no access to international credit markets. Their individual preferences are described by the welfare function

$$
W_{0}=E_{0} \sum_{t=0}^{\infty} \beta^{t} v\left(g_{t}\right)
$$

The welfare index $v$ is assumed to be strictly increasing and strictly concave, and $\beta \in(0,1)$ is the discount factor. The utility function (1) has the following property

$$
\lim _{g \rightarrow 0} v^{\prime}(g)=+\infty
$$

Output is exogenous and stochastic. Output realizations are independently and identically distributed according to the cumulative distribution $F^{\prime}(y)$, with density $F^{\prime}(y)=f(y)$, $E_{t} y_{t+i}=\bar{y}$ with $y \in Y=\left[y^{l}, y^{u}\right]$ and $y>0$ for all periods $t$ and for $i=1,2, \ldots$. Output is assumed to be perishable and tradable.

\footnotetext{
${ }^{7}$ See Wright 2004.
} 
The government is the only participant in the economy that can issue debt in financial markets. Debt is issued to smooth domestic agents' consumption, therefore serving as social insurance or shock absorption. The government dynamic budget constraint is given by

$$
b_{t+1}=R_{t} b_{t}+g_{t}-y_{t}
$$

Equation (2) specifies the evolution of government net stock of public debt $b$ over time. $R$ is the gross interest rate on public debt, and will be determined endogenously. $(g-y)$ denotes the primary fiscal balance of the government.

The mass of creditors consists of a large number of risk-neutral investors, who decide on their optimal portfolio allocation. They are assumed to have two investment options. First, the option of lending to the government, subject to risk of default, denoted $b_{t+1}$. Second, the option to invest in international capital markets and obtain the net risk-free return $r$, denoted $x_{t+1}$. Formally, under precommitment, their problem can be characterized by the following program

$$
\max _{\left\{c_{t}, x_{t+1}, b_{t+1}\right\}} U_{0}=E_{0} \sum_{t=0}^{\infty} \rho^{t} c_{t}
$$

subject to

$$
\begin{gathered}
a_{t+1}=(1+r) x_{t}+R_{t} b_{t}-c_{t} \\
a_{t}=x_{t}+b_{t} \\
a_{0}>0
\end{gathered}
$$

where $c$ denotes consumption of investors.

It is important to highlight some key characteristics of the proposed set up. The economy presents a distributional conflict in a context of heterogeneous agents. Heterogeneity is given by the existence of two types of agents: creditors and consumers. The objective value of investors and of the government is different, resulting in a conflict of interests: transfers to agents are a function of government's decisions in terms of default, in a context in which the government does not care about the welfare of creditors. ${ }^{9}$

\footnotetext{
${ }^{9}$ This can be interpreted in various ways. First, it can be representative of an economy in which all investors are foreign, and therefore the government is not concerned about their welfa re. Second, and more generally, the case in which investors a re either domestic or foreign but the government is not concerned about their welfare either. This could be the case of a political economy equilibrium with electoral competition, with a "poor" majority receiving government transfers. Candidates competing in elections under majority-voting would ha ve to propose a sequence of transfers under electoral competition (see for example Fa rhi a nd Werning 2007 and Farhi, Sleet, Werning and Yeltekin for examples of capital return taxation without commitment).
}

(continued...) 
Another key characteristic of the model is the possibility of default. Default is defined as debt repudiation, at the cost of the economy moving to financial autarchy. If a government cannot commit to "no default", investors internalize the government participation constraint at every period $t$, given by

$$
E_{t} \sum_{n=0}^{\infty} \beta^{n} v\left(g_{t+n}\right) \geq E_{t} \sum_{n=0}^{\infty} \beta^{n} v\left(y_{t+n}\right)
$$

In (7) the left hand side is the discounted welfare of no default in the current period, the right hand side is the discounted welfare of defaulting and moving to autarchy. (7) can be written as

$$
V\left(y_{t}, b_{t}\right) \geq V^{a}
$$

where

$$
\begin{gathered}
V\left(y_{t}, b_{t}\right) \equiv \max _{\left\{b_{t+1}\right\}}\left\{v\left(y_{t}-R_{t} b_{t}+b_{t+1}\right)+\beta \sup \left[V\left(y_{t+1}, b_{t+1}\right) ; V^{a}\right]\right\} \\
V^{a} \equiv v\left(y_{t}\right)+\beta E_{t} \sum_{n=1}^{\infty} \beta^{n-1} v\left(y_{t+n}\right)
\end{gathered}
$$

where the supra-index $a$ denotes "autarchy". As (9) shows, if default takes place, the economy consumes all output, instead of just a share of it, because it would no longer pay interests on public debt. The loss of declaring default is given by the difference between the discounted value of a consumption path under no default, which is smoothed by issuing debt, and a more volatile (but also higher on average, given that debt must no longer be serviced) consumption path in autarchy. It is assumed that preferences and the initial debt stock are such that condition (7)-(8) holds at time $n=0$, implying the sovereign borrower has interest in participating in and maintaining a borrower-creditor relation that allows expenditure smoothing.

In addition, investors internalize the promised value constraint of the government, which indicates that the discounted welfare of the government under the optimal contract should at least be equal to a reservation value $V^{g}$, that is,

$$
E_{0} \sum_{t=0}^{\infty} \beta^{t} v\left(c_{t}\right) \geq V^{g}
$$

Third, the case in which the decisions in the economy a re undertaken by a class of individuals that run the economy and maximize their own welfare. 
The timing of decisions in the model is as follows. At the beginning of each period, output is realized and observed by all the participants in the economy: domestic agents, government and investors. Then the government decides whether to default or not. Then public debt is serviced if default did not take place, optimal net government transfers are made, and consumption by investors and domestic agents proceeds.

\section{SOVEREIGN DEBT CONTRACTS IN AN ENDOWMENT ECONOMY}

The canonical small-open economy model presented in the previous section can have different equilibria depending on the assumption about the ability of the government to commit to policy announcements. Under precommitment, the government announces "no default", which results in a Pareto-optimal allocation of resources. In that case, the government anticipates investors' reaction solving the program (3)-(6). The assumption of competitive risk-neutral international investors implies that in equilibrium the interest rate on government debt is equal to the risk free international interest rate,

$$
1+r=R
$$

Knowing the reaction of investors, as determined by equilibrium condition (12.1), the government chooses $\left(g_{t}, b_{t+1}\right)$ to maximize (1) subject to government budget constraint (2). First order conditions imply

$$
v^{\prime}\left(g_{t}\right)=\beta R E_{t} v^{\prime}\left(g_{t+1}\right)
$$

Equilibrium condition (12.2) determines the optimal fiscal policy in terms of net government transfers and debt accumulation. Government transfers are smoothed over time through public debt issuance, along a path that slopes according to the relative magnitudes of $\beta$ and $R$. Expenditure smoothing is maximum with the government providing full insurance to consumers, in the sense that transitory fluctuations in consumption are completely smoothed out through debt issuance. Public debt acts as a shock absorber.

If the government lacks commitment technology, the solution above is no longer an equilibrium. If preferences and initial parameters are such that (i) the probability of the participation constraint binding at some point in time is greater than zero, and also (ii) there are incentive to participate in a borrowing relation with creditors, a government could optimally choose to default at some point. The solution to the problem under participation constraints is found by solving the problem of the government first, and then solving the optimal investors' decision rules taking into consideration the reaction of the government. International investors now incorporate conditions (7) and (11) in their optimal investment decisions, and offer a debt contract that is acceptable to the government. Formally, investors solve 


$$
\left.\max _{\left\{c_{t}, x_{t+1}, b\right.} b_{t+1}\right\}=E_{0} \sum_{t=0}^{\infty} \rho^{t} c_{t}
$$

subject to

$$
\begin{gathered}
a_{t}=x_{t}+b_{t} \\
x_{t+1}+b_{t+1}=(1+r) x_{t}+R_{t} b_{t}-c_{t} \\
a_{0}>0 \\
E_{0} \sum_{t=0}^{\infty} \beta^{t} v\left(g_{t}\right) \geq V^{g} \\
E_{t} \sum_{n=0}^{\infty} \beta^{n} v\left(g_{t+n}\right) \geq v\left(g_{t}\right)+\beta V^{a} \\
b_{t+1}=R_{t} b_{t}+g_{t}-y_{t}
\end{gathered}
$$

When participation constraints are introduced as part of the investor problem there is no asset losses to investors in equilibrium by construction. As a result, there is no risk premia, and therefore $R_{t}=1+r=R$. The Lagrange function for this problem is given by

$$
\begin{aligned}
& L=E_{0} \sum_{t=0}^{\infty} \rho^{t}\left\{c_{t}+\lambda_{t}\left[(1+r) x_{t}-c_{t}+R b_{t}-b_{t+1}-x_{t+1}\right]\right. \\
& \left.+\gamma_{t} E_{t}\left[\sum_{n=0}^{\infty} \beta^{n} v\left(g_{t+n}\right)-v\left(y_{t}\right)-\beta V^{a}\right]+\varphi\left[v\left(g_{t}\right)-V^{g}\right]\right\}
\end{aligned}
$$

where $\left(\lambda_{t}, \gamma_{t}, \varphi\right)$ are Lagrange multipliers.

Notice that the problem (13) is not recursive. This implies the usual Bellman equation is not satisfied, and the solution can not be written in the form of time-invariant equilibrium decision rules. This is because the participation constraint spans the entire future, and as a result the whole history of past shocks matters in the optimal decision at each point in time. 
Following Marcet and Marimon (2019), the Lagrange function can be transformed in a way such that recursiveness is recovered. Define a set of new state variables as ${ }^{10}$

$$
\begin{gathered}
\theta_{t+1}=\theta_{t}+\gamma_{t} \\
\theta_{0}=0
\end{gathered}
$$

Applying the law of iterated expectations, and using conditions (15), the Lagrange function can be transformed to obtain (see appendix 1) ${ }^{11}$

$$
\begin{aligned}
& H=E_{0} \sum_{t=0}^{\infty} \rho^{t}\left\{c_{t}+\lambda_{t}\left[(1+r) x_{t}-c_{t}+R b_{t}-b_{t+1}-x_{t+1}\right]\right. \\
& \left.+\gamma_{t}\left[v\left(g_{t}\right)-v\left(y_{t}\right)\right]+\theta_{t}\left[v\left(g_{t}\right)-\beta V^{a}\right]+\varphi v\left(g_{t}\right)\right\}-\varphi V^{g}
\end{aligned}
$$

with government transfers evolving according to $b_{t+1}=R b_{t}+g_{t}-y_{t}$, and with the evolution of state and co-state variables on the behavioral constraints of the government specified as in (15). The Khun-Tucker conditions of investors' problem (derived in appendix 2) can be combined to obtain the equilibrium condition that characterizes the optimal sovereign debt contract,

$$
1-\left(\gamma_{t}+\theta_{t}+\varphi\right) v^{\prime}\left(g_{t}\right)=\rho R E_{t}\left[1-\left(\gamma_{t+1}+\theta_{t}+\gamma_{t}+\varphi\right) v^{\prime}\left(g_{t+1}\right)\right]
$$

for an interior solution with positive consumption by investors. The 1s in (17) are the marginal utility of consumption of risk-neutral investors. Notice that (17) includes the marginal utility of the borrowing sovereign, wich captures investor's internalization of a possible default.

Examination of (17) enables the characterization of the paths of public debt, government transfers and consumption of agents in the borrowing economy under various states of nature.

Proposition 1. There is no default in equilibrium and the sovereign risk premium is equal to zero.

As inidcated above, when participation constraints are introduced as part of the investor problem, there is no soverign debt default nor debt repudiation in equilibrium, resulting in no asset loss to investors. Given the assumption of competitive international financial

\footnotetext{
${ }^{10}$ As shown in Marcet and Marimon (2019), the fact that the equivalence between the originalnon-recursive specification of the problem and the transformed problem requires to set $\theta_{0}=0$ has a meaningful economic interpretation. It reflects the time inconsistent nature of the formulated problem. The time inconsistency of the problem can be interpreted as the temptation of the government to set $\theta_{t}=0$ for $t>0$.

${ }^{11}$ See Marcet and Marimon (1998) for a proof of optimality theorems.
} 
markets, and the full internalization of the time onconsistency problem in sovereign debt issuance, the sovereign spread collapses to zero, implying $R_{t}=1+r=R$.

Proposition 2. The optimal sovereign debt contract offered by investors is state contingent.

Inspection of equillibrium condition (17) indicates that optimal lending rules of investors differ depending on whether the participation constraints bind. When random output realizations make default preferable to the sovereign debtor, the value of the Lagrange multipliers becomes positive, affecting the slope of the investors' consumption path. In addition, investors internalize the sovereign's marginal utility in the current and next periods, thereby incorporating the incentives to default in low states. The state contingent nature of the debt contract emerges as an optimal solution from the perspective of the creditor as a result of the internalization of the time-inconsistency problem in sovereign debt issuance. The next propositions characterize the specific properties of the optimal state contingent debt contract.

Proposition 3. In periods in which neither the participation nor the promised value constraint bind, economic dynamics are the same as in the precommitment case: expenditure smoothing is maximum and debt acts as a shock absorber.

Consider first the cases in which the economy is in good states of nature, and neither the participation nor the promised value constraints bind. In those cases, $\gamma_{t}=\varphi=0$, and condition (17) is the same as the Euler equation in the precommitment case for the investor, except for the presence of $\gamma_{t+1} v^{\prime}\left(g_{t+1}\right)$ on the right hand side with a negative sign. This term reflects expectations of a default next period with some probability. When neither constraint binds the government continues to allocate expenditure and to issue debt according to (12.2). Debt evolves as in the precommitment technology case, acting as a shock absorber, given that the interest rate is the same as in the economy with commitment.

Proposition 4. Investors provide net-positive financing to the debtor as a strategy to prevent a default.

Consider now the case in which the participation constraint binds at time $t$, and $\gamma_{t}>0$. Inspection of (17) reveals that $\gamma_{t}>0$ implies a decline in both left and right hand sides of (17), with their relative magnitudes depending on the values of $\rho$ and $R$. Consider, for example, the case of $\rho R=1$. In this case, the effects on both sides of (17) compensate each other. Given that the participation constraint is binding, absence of additional financing would imply a high marginal utility of consumption in period $t$ in the borrowing economy which would lead to a default. To prevent this situation, lenders have to purchase additional debt from the sovereign debtor to finance consumption in the borrowing economy, thereby reducing the marginal utility of consumption in period $t$ at the expense of future consumption due to higher interest payments. The additional financing amount is determined by the level required to maintain the equality in (17). In this way, lenders keep the sovereign borrower engaged in the lending agreement by preventing a sharp decline of consumption that would lead to a default, making low states less painful. In addition, the accumulation of debt reduces 
expected marginal utility of consumption next period, because more resources are devoted to debt servicing. This implies a reduction in marginal utility of consumption in the borrowing economy in low states, and an increase in expected marginal utility of consumption next period. Notice that these two effects tend to equalize both sides of (17) in a period in which participation constraints bind, which by definition implies a high marginal utility of consumption in the current period. The exact amount of additional debt issuance is determined by the resources required to restore the equality in (17), which is just sufficient to prevent a sovereign default.

Proposition 5. In periods in which the participation constraint binds, the contract specifies a downward adjustment in primary expenditures.

The explanation above means that government transfers in low states of nature remains lower than the level they would have had under full insurance. However, the fact that the borrowing economy is issuing debt implies that this decline is lower than the decline in output (consumption declines, but the ratio consumption/output increases). The economy undertakes a "fiscal adjustment" in the form of a reduction of government spending in real terms following adverse shocks such that participation constraints bind. ${ }^{12}$ In other words, social insurance through debt issuance is only partial during periods with incentives to default.

Proposition 6. The stock of debt of the sovereign debtor is lower than in an economy that can commit to no default.

The non-decreasing evolution of the state variable $\theta_{t}$, which follows from the fact that $\gamma_{t} \geqq$ 0 and from its specification in (15), implies that consumption in the borrowing economy is increasing in expected terms, for sufficiently high levels of $\rho$ and $R$-including cases in which $\rho R<1$. If there is a non-zero probability that the participation constraint may bind in $t+1$, then the expected value of $\gamma_{t+1}$ is positive and the summation of Lagrange multipliers on the right side of (17) is larger than on the left side. This implies that government consumption displays an increasing path in expected terms. For this to be feasible, the economy without commitment technology needs to have lower levels of debt than under precommitment, for a given set of parameter values. Notice that this is the case despite interest rate on debt remaining at international levels. The intuition is that creditors optimally lend if debt levels are sufficiently low, so as to leave lending space for additional financing in periods with incentives to default, when debt is expected to increase. In other words, no commitment sets an upper limit on government debt. Low indebtedness can be interpreted as a self-insurance policy, enabling access to financing to smooth consumption in low states such that the participation constraint binds.

\footnotetext{
${ }^{12}$ Fisca 1 consolidations are a stylized factpost sovereign debt restructuring a greements. See for example Easterly 1989.
} 
In sum, the optimal contract keeps all participants engaged in the lending relationship by specifying actions that are better than the consequences of a default to all involved. The government avoids moving to financial autarchy and investors continue receiving debt service payments. The government adjusts expenditures in periods with incentives to default to prevent excessive accumulation of debt. This makes default less likely and ensures future access to financing. The economy is fully insured against "small shocks" such that participation constraints do not bind, as under precommitment, but partially sacrifices insurance against large negative shocks with a downward adjustment in consumption in periods with incentives to default.

\section{SOVEREIGN DEBT CONTRACTS IN AN ECONOMY WITH PRODUCTION}

In a production economy, all assumptions remain the same except that output is produced according to the production function

$$
y_{t}=s_{t} k_{t}^{\alpha}
$$

where $k_{t}$ is the stock of capital. $s_{t}$ is a stochastic shock independently and identically distributed according to the cumulative distribution $F(s)$, with density $F^{\prime}(s)=$ $f(s), E_{t} s_{t+i}=\bar{s}$ and where $s \in S=\left[s^{l}, s^{u}\right], s>0$ for all periods $t$ and for $i=1,2, \ldots \alpha \in$ $(0,1)$. Capital is tradable, and it is used to produce a perishable and tradable good.

The government no longer receives an endowment every period, and must collect resources through output taxes in order to finance expenditures and to service public debt. With production, the problem of the government is given by

$$
\max _{\left\{g_{t}, \tau_{t+1}\right\}} W_{0}=E_{0} \sum_{t=0}^{\infty} \beta^{t} v\left(g_{t}\right)
$$

subject to

$$
\begin{gathered}
b_{t+1}=R_{t} b_{t}+g_{t}-\tau_{t} y_{t} \\
b_{0}>0
\end{gathered}
$$

where $\tau_{t}$ is the tax rate. The tax rate is announced a period in advance. The government cannot invest. This means that it relies on capital invested by investors in order to be able to collect taxes and spend.

The equilibrium of this problem with precommitment is largely the same as that of the endowment economy. The only difference is that the government announces tax rates so that to maximize its objective value. Under the technological assumptions in the model, the optimal tax rate is constant at $\tau=1-\alpha$ (appendix 3 ). With a constant tax rate, investors 
optimal asset allocation decision rules imply a constant level of capital investment in the economy. As a result, output only fluctuates in response to stochastic technology/terms of trade shocks.

Consider now the case of an economy without commitment technology. Notice that the time inconsistency problem is more general in an economy with private capital investment and production. There is no reason to pressume that a sovereign government perceived able and willing to default on debt would be expected to be fully committed to honor other commitments, such as tax rates that can also be used to increase concurrent domestic consumption in bad states of nature. Two deviations from policy annuncements now become possible. First, as above, the government can deviate from the promise of "no default" on debt. Second, the government can deviate from the announced tax rate. Moreover, given the government relies on capital investment to obtain output and tax revenue, the government can also impose restrictions on divestment and capital mobility. ${ }^{13}$

The results above imply that the government's value of doing default and moving to autarchy at time $t$ is given by

$$
\begin{gathered}
V^{a}\left(s_{t}, k_{t}\right)=\max _{\left\{k_{t+1}\right\}}\left\{v\left(s_{t} k_{t}^{\alpha}+k_{t}-k_{t+1}\right)+\beta V^{a}\left(s_{t+1}, k_{t+1}\right)\right\} \\
k_{t+1} \leq k_{t}
\end{gathered}
$$

where, as before, supra-index $\alpha$ denotes "autarchy". Equation (2) captures the fact that after default takes place the government can transfer the whole output proceed to domestic agents having no capital plus imports, instead of just the share collected from taxation. Trade decisions are determined by the choice of $k_{t+1}$. If $k_{t+1} \leq k_{t}$ then the government sells capital at time $t$ to finance a trade deficit. Otherwise $k_{t+1}=k_{t}$, as determined by the assumption that the government can not invest.

The optimal sovereign debt contract with production is obtained from the equilibrium conditions resulting from the problem:

\footnotetext{
${ }^{13}$ In fact, this is the optimal devia tion by the government if, for example, investors' trigger strategy in an event of a debt default includes divestment and moving the capital stock out of the economy. If this was the case, under subgame perfection equilibria, in a default the government would optimally set the tax ra te equal to one, transfering a ll output to domestic consumers. To sustain th is in financial a utarchy, the government would also need to forbid capital mobility to prevent investors from divesting and taking capital out of the economy. As a result, a fter default occurs, the only source of consumption smoothing available to the government is international trade. In the model, the assumption that the government cannot invest implies that the capital stock declines in expected terms after a default.
} 


$$
\max _{\left\{c_{t}, x_{t+1}, k_{t+1}, b_{t+1}\right\}} U_{0}=E_{0} \sum_{t=0}^{\infty} \rho^{t} c_{t}
$$

subject to

$$
\begin{gathered}
x_{t+1}+k_{t+1}+b_{t+1}=\left(1-\tau_{t}\right) s_{t} k_{t}^{\alpha}+(1+r) x_{t}+R_{t} b_{t}+k_{t}-c_{t} \\
a_{t}=x_{t}+k_{t}+b_{t} \\
a_{0}>0 \\
E_{0} \sum_{t=0}^{\infty} \beta^{t} v\left(g_{t}\right) \geq V^{g} \\
E_{t} \sum_{n=0}^{\infty} \beta^{n} v\left(g_{t+n}\right) \geq V^{a}\left(s_{t}, k_{t}\right) \\
b_{t+1}=R_{t} b_{t}+g_{t}-\tau_{t} s_{t} k_{t}^{\alpha} \\
k_{t+1} \leq k_{t}
\end{gathered}
$$

The optimal sovereign contract can be shown to take the form (see appendix 4)

$$
\begin{gathered}
1-\left(\gamma_{t}+\theta_{t}+\varphi\right) v^{\prime}\left(g_{t}\right)= \\
+\rho R E_{t}\left[1-\left(\gamma_{t+1}+\theta_{t}+\gamma_{t}+\varphi\right) v^{\prime}\left(g_{t+1}\right)\right] \\
r=E_{t}\left\{\alpha^{2} \frac{y_{t+1}}{k_{t+1}}-\left(\gamma_{t+1}+\theta_{t}+\gamma_{t}+\varphi\right) v^{\prime}\left(g_{t+1}\right)(1-\alpha) \alpha \frac{y_{t+1}}{k_{t+1}}\right. \\
\left.-\gamma_{t+1} V_{k}^{a}\left(s_{t+1}, k_{t+1}\right)+\mu_{t}-\mu_{t+1}\right\}
\end{gathered}
$$

where (21.2) is written for the special case in which there is both financialand trade autarchy if default occurs..$^{14}(21.1)$ is the same as the endowment case, which implies that all the results of the endowment economy apply for the economy with production.

\footnotetext{
${ }^{14}$ This is a simplification that does notaffect the nature and economics of the contract and abstracts from non essential terms (see appendix 4 for the complete expression with financiala utarchy only).
} 
The addition of production and the assumption of possible loss of capital returns through increases in taxes and imposition of capital controls makes investors more cautious about investing in the economy. The contract now includes an optimal investment allocation rule. Risk neutral investors compare the expected return of investing in the economy, as determined by the right-hand side of (21.2), with the opportunity cost of investing in international risk-free assets. The first term on the right-hand side is the usual Euler equation term under commitment, and accounts for the expected returns of saving a unit of capital at time $t$ to be invested in the economy and receive expected returns, which are equal to the marginal productivity of capital net of tax deductions. The remaining two terms are specific to an economy that can default. The first of them is related to the internalization on the part of investors of the value of the government of honoring the contract if either constraint binds. The second is the investors' internalization of the government value of moving to autarchy. These last terms in (21.2) reveal additional features of the contract in a production economy.

Proposition 7. If a government that can default on public debt can also appropriate returns on assets invested in the economy above the amount implied by the announced tax rate, then the stock of capital is lower than that of an economy with commitment technology.

Notice first that all terms in (21.2) are exogenous or predetermined. The only way investors can act to ensure this condition is met in periods with incentives to default is to increase capital investment in the economy, so as to increase future expected tax revenue.

Consider the case in which neither the participation nor the promised value constraint bind. In that case, $\gamma_{t}=\varphi=0 . \theta_{t} \geq 0$ depending on the extent to 2 which the participation constraint bind in the past. In that case, the second and third terms on the right hand side of (21.2) have a negative expected value, provided there is positive probability of the participation constraint binding at $t+1$, that is, provided $E_{t} \gamma_{t+1}>0$. This implies that investors' expected return of capital investment is lower than in an economy that cannot default. As a result a rational investor would invest less in this economy than in an economy with precommitment technology on tax rate announcements.

Proposition 8. If the government default constraint binds at time $t$, investors optimally increase capital investment in the economy. This increases expected tax revenues and government expenditure next period, keeping the government participating in the contractual debt agreement.

To show this is the case, suppose at time $t$ the participation and/or the promised value constraint bind and $\gamma_{t}+\varphi>0$. This reduces the value of the right side of (21.2) through the Lagrange multipliers effect. In order for (21.2) to continue holding with equality, some other term on the right hand side should increases in value. The only way investors can do so is by increasing the amount of capital invested in the economy. In this way, expected output increases, and so do expected revenues and government expenditures. This means that investors avoid the costs of a default by increasing future consumption and welfare in the borrowing economy. 
The simulatenous combination of equilibrium conditions (21) implies that, everything else equal, the concurrent government financing required to avoid a default is lower than in an endowment economy because part of the welfare loss in the current period can be compensated with additional welfare gains through higher output and tax revenue. ${ }^{15}$

\section{Proposition 9. The stock of capital is increasing in expected terms.}

This last proposition follows from the previous two. With some probability the participation and/or the promised value constraint bind and the investor finds it optimal to increase the stock of capital. If neither constraint binds at time $t$, then capital remains constant.

\section{CONCLUSION}

This paper derives an optimal recursive sovereign debt contract for a canonical small-open economy model with sovereign default. In the model, the government is not concerned with the welfare of creditors and it only values the welfare of domestic consumers to whom it makes transfers for consumption smoothing and/or social insurance. Lacking commitment technology, the government can optimally default on debt at any point in time if the value of defaulting to support concurrent consumption is higher than the value of continuing to service public debt to maintain access to finacing in the future.

Internalization of these incentives by rational investors results in an optimal state-contingent sovereign debt contract, with the following characteristics: (i) there is no sovereign default in equilibrium; (ii) as a result, there is no risk premia in equilibrium and the sovereign's borrowing interest rates remain at the international "risk-free" level; (iii) the borrowing sovereign economy remains "fully insured" through debt issuance against relatively small aggregate shocks such that the default constraint is not binding; (iv) there is net-positive financing (above automatic rescheduling of maturing obligations) when the default constraint binds, keeping the sovereign debtor engaged in the lending agreement and eliminating the creditor's asset loss; (v) issuance of SCDIs is optimal at all times, and not just as part of a debt-restructuring offer nor other specific circumstances; (vi) the interestrate paid by the sovereign borrower is not state contingent; (vii) the sovereign borrower is required to do a fiscal consolidation when the default constraint triggers, which is small enough to keep the sovereign debtor engaged in the contractual debt agreement; and (viii) the soveregin debtor is required to have low levels of debt compared to the case of full commitment.

\footnotetext{
${ }^{15}$ Notice the actions of creditors and capital investors do not need to be coordinated for an equilibrium with state-contingent debt contracts to hold. A priori, there is no reason to preempt that capital investors would internalize the potential losses of a debt investor/creditor, and vicebersa. Competitive assumptions, however, warrant the result. A debt holder could a lways purchase ca pital investments and ensure both optimal debt contract conditions in an economy with capital and production are met. This is a kin to capital loosing value when a default is imminent (in light of the government optimal deviation to the tax rate on capital returns) and then having investors purchase the capital stock and invest enough to prevent a default.
} 
The specifics of the state-contingent contract above do not support the use of pro-cyclical debt service clauses that have been proposed in the literature, mainly the indexation of debt service payments to indicators of debt service capacity such as output, exports, terms of trade, or government revenue. Intuitivelly, these forms of state-contingency are sensible as a bussiness cycle stabilization device and to reduce the probability of a default. However, the results in this paper indicate a that pro-cyclical indexation of debt service is suboptimal, for the following resons. First, it implies that the shock and debt service capacity/willigness uncertainty is partially transferred to creditors. Default remains possible in equilibrium and thereby priced with a sovereign risk premia (including for relativelly smaller cyclical fluctuations when the participation constraint does not bind). Second, it would prevent borrower's maximum expenditure smoothing as under the optimal contract in periods with with relatively small shocks with no incentive to default. For example, in the face of a negative terms of trade shock, a sovereign creditor would seek additional financing for consumption stabilization. In doing that, however, it would increase debt carried into next period, therefore increassing the risk of a default in the future and the sovereign risk premium. In this way, the risk of default would not be eliminated with pro-cyclical indexation, but only reduced. Confronted with this situation, the sovereign borrower would optimally seek only partial insurance: supporting consumption today comes at the cost of sacrificing consumption tomorrow. This contrasts with the optimal contract specification where, as noted above, the elimination of default in equilibrium implies that the risk premium is zero and therefore there is no increase in the borrowing interest rate, thus eliminating the intertemporal consumption trade off and allowing maximum expenditure smooting and social insurance.

The features of the optimal contract can be instrumented with SCDIs, albeit some of them differ from several of the proposals in the literature. The results and specific assumptions in this paper indicate that sovereign bonds and loans could inlcude trigger clausses for automatic positive net financing under large negative shocks that are exogenous, recurrent, and verifiable - as needed to rule out moral hazard and adverse selection considerations. Examples of such shocks include natural disasters or pandemics. Also, countries could issue these instruments for current and capital account shocks that can be assessed as exogenous and unrelated to unsustainable domestic policies. For example, contingent clauses could trigger automatically for suffciently large current account shocks, and/or sudden stops (sharp capital account reversals) that can be demonstrated to be part of a global trend. The automatic trigger could be linked to the sovereign borrower meeting specific verifiable pre-conditions such as, for example, a sustainable fiscal and external position as assessed by an independent institution such as the International Monetary Fund, or if the country has agreed to a Fundsupported program committing to a sustainable macroeconomic framework.

One constraint affecting the use of SCDIs is the markets' reluctance to accept them. To work in practice for sovereign debtors, SCDIs need to be isued in a sufficiently large critical mass so as to provide significant debt service relief of macroeconomic relevance for the country. This requires wide acceptance of such instruments in financial markets. However, this is not 
the case in reality. Financial markets have thus far shown reluctance to take up these type of instruments, mostly based on complexity, transparency, and liquidity concerns. ${ }^{16}$ This is an interesting observation considering the state-contingent debt contract in this paper emerges as an optimal solution from the creditor/investor perspective - in contrast with the the studies in the literature noted above that analyze the benefits to the debtor by an ad-hoc introduction of SDCIs. A key assumption behind this result in the stylized model in this paper is that investors are endowed with "deep pockets" and face no liquidity constraints: they can invest and sell assests at will in international financial markets at the risk free international interest rate. This is a simplifying assumption in the realm of a stylized model, but not a feature of real life where liquidity constraints matter-for example, by the activation of margin calls. ${ }^{17}$

However, the "deep pockets" investors assumption can shed light on the nature of the constraint preventing the full development of a market for SCDIs. As already mentioned, shock verifiability and transparency are key for market development, and SCDIs are by design more demanding on these fronts than non-contingent instruments. SCDIs market development could be supported with the design of benchamrk instruments and a robust market infrastructure. However, this would not necessarily address investors' liquidity risk: the development of a SCDIs market could be subject to a investor coordination, or "chiken and egg", problem. A sufficiently large mass of these bonds, issued by many sovereign borrowers, is needed for an appropriate diversification by international investors. No country nor investor can achieve this in isolation. A concerted effort led by financial asset trading authorities in major international financial markets could be coordinated to allow a critical mass of creditor/investors to issue SCDIs, paving the way to the development of a market for SCDIs global tradeability, thereby increasing their liquidity. Participation of institutional investors in such market that face less liquidity risk and relatively more concerned with longterm capital preservation, such as pension and insurance funds, could facilitate the emergence of a market for SCDIs.

\footnotetext{
${ }^{16}$ See International Monetary Fund (2017) for a summary of reasons why financialmarkets have thus far shown reluctance to a ccess state-contingent clauses in debt contracts in large a mounts.

${ }^{17}$ Roch and Roldan (2021) offer an explanation for the low ma rket a cceptability for SCDIs based on model uncertainty faced by "robust" international creditors - creditors a re uncertain about the underlying income process of borrowers a nd a ttach high probability to rela tively morepessimistic outcomes. They show that debt issuers can find it optimal to issue SCDIs, but this comes at a premium given robust investors' discounting. According to their results, this reduces the desirability of SCDIs when the risk premia, obtained through this lens, is ca librated to the data. Their explanation, however, omits the consideration of preference for liquidity typical of financial institutions, especially banks, credit unions, and securities' dealers.
} 


\section{Appendix 1. Transformation of the Lagrange function for an endowment economy}

The Lagrange function for the problem of foreign investors in the economy is given by

$$
\begin{gathered}
L=E_{0} \sum_{t=0}^{\infty} \rho^{t}\left\{c_{t}+\lambda_{t}\left[(1+r) x_{t}-c_{t}+R b_{t}-b_{t+1}-x_{t+1}\right]\right. \\
\left.+\gamma_{t} E_{t}\left[\sum_{n=0}^{\infty} \beta^{n} v\left(g_{t+n}\right)-v\left(y_{t}\right)-\beta V^{a}\right]\right\}+\varphi\left[E_{0} \sum_{t=0}^{\infty} \beta^{t} v\left(g_{t}\right)-V^{g}\right]
\end{gathered}
$$

The infinite summation on the participation constraint in the Lagrange function above, given by

$$
E_{0} \sum_{t=0}^{\infty} \beta^{t} \gamma_{t} E_{t}\left[\sum_{n=0}^{\infty} \beta^{n} v\left(g_{t+n}\right)-v\left(y_{t}\right)-\beta V^{a}\right]
$$

can be re-written as

$$
E_{0} \sum_{t=0}^{\infty} \beta^{t} \gamma_{t}\left[v\left(g_{t}\right)-v\left(y_{t}\right)-\beta V^{a}\right]+E_{0} \sum_{t=0}^{\infty} \gamma_{t} \sum_{n=1}^{\infty} \beta^{t+n} v\left(g_{t+n}\right)
$$

The second term can be expanded as follows:

For $t=0:\left(\theta_{1}-\theta_{0}\right) \beta v\left(g_{1}\right)+\left(\theta_{1}-\theta_{0}\right) \beta^{2} v\left(g_{2}\right)+\left(\theta_{1}-\theta_{0}\right) \beta^{3} v\left(g_{3}\right)+\ldots$

For $t=1:\left(\theta_{2}-\theta_{1}\right) \beta^{2} v(g)+\left(\theta_{2}-\theta_{1}\right) \beta^{3} v\left(g_{3}\right)+\left(\theta_{2}-\theta_{1}\right) \beta^{4} v\left(g_{4}\right)+\ldots$

For $t=1:\left(\theta_{3}-\theta_{2}\right) \beta^{3} v\left(g_{3}\right)+\left(\theta_{3}-\theta_{2}\right) \beta^{4} v\left(g_{4}\right)+\left(\theta_{3}-\theta_{2}\right) \beta^{5} v\left(g_{5}\right)+\ldots$ and so on.

After simplifying terms,

For $t=0:\left(-\theta_{0}\right)\left[\beta\left(g_{1}\right)+\beta^{2} v\left(g_{2}\right)+\beta^{3} v\left(g_{3}\right)+\ldots\right]+\theta_{1} \beta v\left(g_{1}\right)$

For $t=1: \theta_{2} \beta^{2} v\left(g_{2}\right)$

For $t=2: \theta_{3} \beta^{3} v\left(g_{3}\right)$

and so on.

Imposing $\theta_{0}=0$, the infinite summation can be written as 


$$
E_{0} \sum_{t=1}^{\infty} \beta^{t} \theta_{t} v\left(g_{t}\right)
$$

This implies that the participation constraint can be written as follows

$$
E_{0} \sum_{t=0}^{\infty} \beta^{t} \gamma_{t}\left[v\left(g_{t}\right)-v\left(y_{t}\right)\right]+E_{0} \sum_{t=0}^{\infty} \beta^{t} \theta_{t}\left[v\left(g_{t}\right)-\beta V^{a}\right]
$$

Equation (A1.3) can be replaced in the participation constraint of the Lagrange function $L$ to obtain $H$.

\section{Appendix 2. Derivation of optimal sovereign debt contract for an endowment economy}

Recall the modified Lagrange function (16):

$$
\begin{aligned}
& H=E_{0} \sum_{t=0}^{\infty} \rho^{t}\left\{c_{t}+\lambda_{t}\left[(1+r) x_{t}-c_{t}+R b_{t}-b_{t+1}-x_{t+1}\right]\right. \\
& \left.+\gamma_{t}\left[v\left(g_{t}\right)-v\left(y_{t}\right)\right]+\theta_{t}\left[v\left(g_{t}\right)-\beta V^{a}\right]+\varphi v\left(g_{t}\right)\right\}-\varphi V^{g}
\end{aligned}
$$

The Kuhn-Tucker conditions of the investor problem under participation constraints, recalling that $c_{t}=y_{t}-R b_{t}+b_{t+1}$, are given by

$$
\begin{gathered}
1-\lambda_{t} \leq 0 \text { and }=0 \text { if } c_{t}>0 \\
-\lambda_{t}+\rho(1+r) E_{t} \lambda_{t+1} \leq 0 \text { and }=0 \text { if } x_{t+1}>0 \\
-\lambda_{t}+\left(\gamma_{t}+\theta_{t}+\varphi\right) v^{\prime}\left(g_{t}\right)+\rho E_{t} R\left[\lambda_{t+1}\right. \\
\left.-\left(\gamma_{t+1}+\theta_{t+1}+\varphi\right) v^{\prime}\left(g_{t+1}\right)\right] \leq 0 \text { and }=0 \text { if } b_{t+1}>0 \\
v\left(c_{t}\right)+\sum_{n=1}^{\infty} \beta^{n} v\left(g_{t+n}\right)-v\left(y_{t}\right)-\beta V^{a} \geqq 0 \text { and }=0 \text { if } \gamma_{t}>0 \\
E_{0} \sum_{t=0}^{\infty} \beta^{t} v\left(g_{t}\right)-V^{g}=0 \\
(1+r) x_{t}-c_{t}+R b_{t}-b_{t+1}-x_{t+1}=0
\end{gathered}
$$


and with the state and co-state variables evolving according to $\theta_{t+1}=\theta_{t}+\gamma_{t}$ with $\theta_{0}=0$. These conditions for an interior solution can be combined to obtain

$$
1-\left(\gamma_{t}+\theta_{t}+\varphi\right) v^{\prime}\left(g_{t}\right)=\rho R E_{t}\left[1-\left(\gamma_{t+1}+\theta_{t+1}+\varphi\right) v^{\prime}\left(g_{t+1}\right)\right]
$$

which is the same as equation (17) in the text and specifies the optimal recursive sovereign debt contract.

\section{Appendix 3. Derivation of the optimal tax rate under precommitment}

Assuming the government will not reoptimize after the stock of capital and the level of public debt have been decided and the tax rate has been announced, the optimization problem of the government is to choose the tax rate that would maximize expected tax revenues the next period:

$$
\max E_{t} \tau_{t+1} s_{t+1} k_{t+1}^{\alpha}
$$

subject to

$$
1+\alpha E_{t} S_{t+1}\left(1-\tau_{t+1}\right) k_{t+1}^{\alpha-1}=(1+r)
$$

or, equivalently,

$$
\max _{\tau_{t+1}} E_{t} \tau_{t+1} S_{t+1}\left[\frac{\alpha s_{t+1}\left(1-\tau_{t+1}\right)}{r}\right]^{\frac{\alpha}{1-\alpha}}
$$

The assumptions ensure that this problem displays a unique and interior solution. The first order condition is given by

$$
E_{t} s_{t+1}\left[\frac{\alpha s_{t+1}\left(1-\tau_{t+1}\right)}{r}\right]^{\frac{\alpha}{1-\alpha}}-E_{t} \tau_{t+1} s_{t+1}\left[\frac{\alpha^{2} s_{t+1}}{(1-\alpha) r}\right]\left[\frac{\alpha s_{t+1}\left(1-\tau_{t+1}\right)}{r}\right]^{\frac{2 \alpha-1}{1-\alpha}}=0
$$

Operating algebraically, and exploiting the fact that under precommitment announced tax rates can not be changed,

$$
\left[\left(1-\tau_{t+1}\right)^{\frac{\alpha}{1-\alpha}}-\tau_{t+1}\left(\frac{\alpha}{1-\alpha}\right)\left(1-\tau_{t+1}\right)^{\frac{2 \alpha-1}{1-\alpha}}\right] E_{t} s_{t+1}\left(\frac{\alpha s_{t+1}}{r}\right)^{\frac{\alpha}{1-\alpha}}=0
$$

Since the term under the expectations operator is strictly positive, the pre-announced tax rate under precommitment can be obtained by equating to zero the term in brackets. Solving for the tax rate one obtains

$$
\tau_{t+1}=1-\alpha=\tau
$$




\section{Appendix 4. Optimal investment rules in an economy with production}

The Lagrange function for the investor.s problem is as given by

$$
\begin{aligned}
& L=E_{0} \sum_{t=0}^{\infty} \rho^{t}\left\{c_{t}+\lambda_{t}\left[(1-\tau) s_{t} k_{t}^{\alpha}+(1+r) x_{t}+k_{t}-c_{t}+R b_{t}-b_{t+1}-x_{t+1}-k_{t+1}\right]\right. \\
& \left.+\gamma_{t} E_{t}\left[\sum_{n=0}^{\infty} \beta^{n} v\left(g_{t+n}\right)-V^{a}\left(s_{t}, k_{t}\right)\right]+\varphi\left[v\left(g_{t}\right)-V^{g}\right]+\mu\left[k_{t+1}-k_{t}\right]\right\}
\end{aligned}
$$

where $\lambda_{t}, \gamma_{t}, \varphi$ and $\mu_{t}$ are Lagrange multipliers. To obtain a recursive maximand, transform the Lagrange function as before, using the same set of state variables

$$
\begin{gathered}
\theta_{t+1}=\theta_{t}+\gamma_{t} \\
\theta_{0}=0
\end{gathered}
$$

Following the same procedure of appendix 1, the Lagrange function above can be transformed to (see appendix 5)

$$
\begin{aligned}
H=E_{0} & \sum_{t=0}^{\infty} \rho^{t}\left\{c_{t}+\lambda_{t}\left[(1-\tau) s_{t} k_{t}^{\alpha}+(1+r) x_{t}+k_{t}-c_{t}+R b_{t}-b_{t+1}-x_{t+1}-k_{t+1}\right]\right. \\
& \left.+\gamma_{t}\left[v\left(g_{t}\right)-V^{a}\left(s_{t}, k_{t}\right)\right]+\theta_{t}\left[v\left(g_{t}\right)\right]+\varphi v\left(g_{t}\right)+\mu\left[k_{t+1}-k_{t}\right]\right\}-\varphi V^{g}
\end{aligned}
$$

with government transfers evolving according to

$$
b_{t+1}=R_{t} b_{t}+g_{t}+\tau_{t} s_{t} k_{t}^{\alpha}
$$

and with the evolution of state and co-state variables on the behavioral constraints of the government specified as in (21).

The Kuhn-Tucker conditions for this problem are given by

$$
\begin{gathered}
1-\lambda_{t} \leq 0 \text { and }=0 \text { if } c_{t}>0 \\
-\lambda_{t}+\rho(1+r) E_{t} \lambda_{t+1} \leq 0 \text { and }=0 \text { if } x_{t+1}>0 \\
-\lambda_{t}+\mu_{t}-\rho E_{t}\left\{\lambda_{t+1}\left[1+\left(1-\tau_{t+1}\right) \alpha \frac{y_{t+1}}{k_{t+1}}\right]\right.
\end{gathered}
$$




$$
\begin{gathered}
\left.-\left(\gamma_{t+1}+\theta_{t+1}+\varphi\right) v^{\prime}\left(g_{t+1}\right) \tau_{t+1} \alpha \frac{y_{t+1}}{k_{t+1}}\right\}>0 \\
\left.-\gamma_{t+1} V_{k}^{a}\left(s_{t+1}, k_{t+1}\right)-\mu_{t+1}\right\} \leq 0 \text { and }=0 \text { if } k_{t+1}>0 \\
-\lambda_{t}-\left(\gamma_{t}+\theta_{t}+\varphi\right) v^{\prime}\left(g_{t}\right)+\rho E_{t} R_{t+1}\left[\lambda_{t+1}\right. \\
\left.+\left(\gamma_{t+1}+\theta_{t+1}+\varphi\right) v^{\prime}\left(g_{t+1}\right)\right] \leq 0 \text { and }=0 \text { if } b_{t+1}>0 \\
v\left(g_{t}\right)+\sum_{n=1}^{\infty} \beta^{n} v\left(g_{t+n}\right)-v\left(s_{t} k_{t}^{\alpha}\right)-\beta V^{a} \geqq 0 \text { and }=0 \text { if } \gamma_{t}>0 \\
E_{0} \sum_{t=0}^{\infty} \beta^{t} v\left(g_{t}\right)-V^{g}=0 \\
\left(1-\tau_{t}\right) s_{t} k_{t}^{\alpha}+(1+r) x_{t}-c_{t}+R b_{t}-b_{t+1}-x_{t+1}-k_{t+1}=0 \\
k_{t+1}-k_{t} \leq 0 \text { and }=0 \text { if } \mu_{t}>0
\end{gathered}
$$

where sub-index $k$ indicates partial derivative with respect to the capital stock and where the state and co-state variables evolve according to $\theta_{t+1}=\theta_{t}+\gamma_{t}$ with $\theta_{t}=0$.

Conditions (A4.6) and (A4.7) are the core investment and lending rules. With the tax rate defined as in (17) and assuming that $c_{t}>0$ and $k_{t}>0$ (interior solution), equilibrium conditions ((A4.6) and (A4.7) can be written as

$$
\begin{gathered}
1-\mu_{t}=\rho E_{t}\left\{\left[1+\alpha^{2} \frac{y_{t+1}}{k_{t+1}}\right]\right. \\
-\left(\gamma_{t+1}+\theta_{t+1}+\varphi\right) v^{\prime}\left(g_{t+1}\right) \tau_{t+1} \alpha \frac{y_{t+1}}{k_{t+1}} \\
\left.-\gamma_{t+1} V_{k}^{a}\left(s_{t+1}, k_{t+1}\right)-\mu_{t+1}\right\} \\
1-\left(\gamma_{t}+\theta_{t}+\varphi\right) v^{\prime}\left(g_{t}\right)= \\
+\rho E_{t} R_{t+1}\left[1-\left(\gamma_{t+1}+\theta_{t}+\gamma_{t}+\varphi\right) v^{\prime}\left(g_{t+1}\right)\right]
\end{gathered}
$$

Conditions (A4.12) and (A4.13), together with the equation for the evolution of the added state variable equation $\theta_{t+1}=\theta_{t}+\gamma_{t}$, characterize the optimal joint debt and investment contract. 
In an interior solution, equilibrium conditions (A4.4) and (A4.5) can be used to express (A4.14) as

$$
\begin{gathered}
r=E_{t}\left\{\left[\alpha^{2} \frac{y_{t+1}}{k_{t+1}}\right]-\left(\gamma_{t+1}+\theta_{t}+\gamma_{t}+\varphi\right) v^{\prime}\left(g_{t+1}\right)(1-\alpha) \alpha \frac{y_{t+1}}{k_{t+1}}\right. \\
\left.-\gamma_{t+1} V_{k}^{a}\left(s_{t+1}, k_{t+1}\right)+\mu_{t}-\mu_{t+1}\right\}
\end{gathered}
$$

Equations (A4.13) and (A4.14) are the same as equations (21) in the text.

\section{Appendix 5. Transformation of the Lagrange Function $L$ to obtain the transformed- Lagrange function $\mathrm{H}$}

The Lagrange function for the problem facing foreign investors in the economy is given by

$$
\begin{gathered}
L=E_{0} \sum_{t=0}^{\infty} \beta^{t}\left\{c_{t}+\lambda_{t}\left[(1-\tau) s_{t} k_{t}^{\alpha}+(1+r) x_{t}+k_{t}-c_{t}+R b_{t}-b_{t+1}-x_{t+1}-k_{t+1}\right]\right. \\
\left.\quad+\gamma_{t} E_{t}\left[\sum_{n=0}^{\infty} \beta^{n} v\left(g_{t+n}\right)-V^{a}\left(s_{t}, k_{t}\right)\right]\right\}+\varphi\left[E_{0} \sum_{t=0}^{\infty} \beta^{t} v\left(g_{t}\right)-V^{g}\right]
\end{gathered}
$$

Using (20), the infinite summation on the participation constraint

$$
E_{0} \sum_{t=0}^{\infty} \beta^{t} \gamma_{t} E_{t}\left[\sum_{n=0}^{\infty} \beta^{n} v\left(g_{t+n}\right)-V^{a}\left(s_{t}, k_{t}\right)\right]
$$

can be written as

$$
E_{0} \sum_{t=0}^{\infty} \beta^{t} \gamma_{t}\left[v\left(g_{t}\right)-V^{a}\left(s_{t}, k_{t}\right)\right]+E_{0} \sum_{t=0}^{\infty} \gamma_{t} \sum_{n=1}^{\infty} \beta^{t+n} v\left(g_{t+n}\right)
$$

The second term can be expanded as follows:

For $t=0:\left(\theta_{1}-\theta_{0}\right) \beta v\left(g_{1}\right)+\left(\theta_{1}-\theta_{0}\right) \beta^{2} v\left(g_{2}\right)+\left(\theta_{1}-\theta_{0}\right) \beta^{3} v\left(g_{3}\right)+\ldots$

For $t=1:\left(\theta_{2}-\theta_{1}\right) \beta^{2} v\left(g_{2}\right)+\left(\theta_{2}-\theta_{1}\right) \beta^{3} v\left(g_{3}\right)+\left(\theta_{2}-\theta_{1}\right) \beta^{4} v\left(g_{4}\right)+\ldots$

For $t=1:\left(\theta_{3}-\theta_{2}\right) \beta^{3} v\left(g_{3}\right)+\left(\theta_{3}-\theta_{2}\right) \beta^{4} v\left(g_{4}\right)+\left(\theta_{3}-\theta_{2}\right) \beta^{5} v\left(g_{5}\right)+\ldots$

and so on.

After simplifying terms, 
For $t=0:\left(-\theta_{0}\right)\left[\beta\left(g_{1}\right)+\beta^{2} v\left(g_{2}\right)+\beta^{3} v\left(g_{3}\right)+\ldots\right]+\theta_{1} \beta v\left(g_{1}\right)$

For $t=1: \theta_{2} \beta^{2} v\left(g_{2}\right)$

For $t=2: \theta_{3} \beta^{3} v\left(g_{3}\right)$

and so on.

Imposing $\theta_{0}=0$, the infinite summation can be written as

$$
E_{0} \sum_{t=1}^{\infty} \beta^{t} \theta_{t} v\left(g_{t}\right)
$$

This implies that the participation constraint can be written as follows

$$
E_{0} \sum_{t=0}^{\infty} \beta^{t} \gamma_{t}\left[v\left(g_{t}\right)-V^{a}\left(s_{t}, k_{t}\right)\right]+E_{0} \sum_{t=0}^{\infty} \beta^{t} \theta_{t}\left[v\left(g_{t}\right)\right]
$$

Equation (A1.3) can be replaced in the participation constraint of the Lagrange function $L$ to obtain $H$. 


\section{REFERENCES}

Barr, D., Bush, O., and Pienkowski, A., 2014, "GDP-Linked Bonds and Sovereign Default," Bank of England Working Paper No. 484.

Benford, J., Best, T., and Joy, M., (with contributions from other central banks), 2016, "Sovereign GDP-Linked Bonds," Bank of England Financial Stability Paper No. 39, (September 2016).

Besley, T., and Powell, A., 1989, "Commodity Indexed Debt in International Lending,” PPR Working Paper No. 161, Washington: The World Bank.

Blanchard, O., P. Mauro, and Acalin, J., 2016, “The Case for Growth Indexed Bonds in Advanced Economies Today," Peterson Institute for International Economics, Policy Brief No. 16-2.

Borensztein, E., and Mauro, P., 2004, "The Case for GDP-Indexed Bonds," Economic Policy, Vol. 19, No. 38, pp. 166-216.

Bowman, J., and Naylor, P., 2016, “GDP-Linked Bonds," Reserve Bank of Australia Bulletin, (September Quarter 2016).

Brooke, M., Mendes, R., Pienkowski, A., and Santor, E., 2013, "Sovereign Default and State-Contingent Debt," Bank of England Financial Stability Paper No 27.

Cabrillac, B., Gauvin, L., Gossé, J.B., 2017, “GDP-Indexed Bonds: What are The Benefits for Issuing Countries, Investors and International Financial Stability?" Quarterly Selection of Articles Banque de France No. 44 (Winter 2016-17).

Carnot, N. and S. Pamies Sumner, 2017. “GDP-linked Bonds: Some Simulations on EU Countries", European Commission, Discussion Paper, 073.

Cecchetti, S., and Schoenholtz, K., 2017 “GDP-Linked Bonds: A Primer,” VOX. Available at: http://voxeu.org/article/gdp-linked-bonds-primer.

Chari V. and Kehoe P. (1990)."Sustainable Plans". Journal of Political Economy No. 98, 783-802.

Cohen D. and Sachs J. (1986). "Growth and External Debt Under Risk of Debt Repudiation." European Economic Review 30(June): 529-60.

Cole H. and Kehoe P. (1995). "The Role of Institutions in Reputation Models of Sovereign Debt." Journal of Monetary Economics 35 (February):45-64. 
Consiglio, A., and Zenios, S., 2015, "The Case for Contingent Convertible Debt for Sovereigns," Working Papers from University of Pennsylvania, Wharton School, Weiss Center.

Dooley M. (1986). "An Analysis of the Debt Crisis". Working Paper No.86/14, International Monetary Fund (December).

Easterly W. (1989). "Fiscal Adjustment and Deficit Financing During the Debt Crisis". In Dealing with the Debt Crisis, edited by Ishrat Husain and Ishac Diwan. Washington D.C.: World Bank.

Eaton J. (1990). "Debt Relief and the International Enforcement of Loan Contracts." Journal of Economic Perspectives Vol. 4, No. 1 (Winter), pp. 43-56.

Eaton J. and Gersovitz M. (1981). "Debt with Potential Repudiation."Review of Economic Studies 48, 289-309.

Eaton J., Gersovitz M. and Stiglitz J. (1986). "The Pure Theory of Country Risk." European Economic Review, 30, No. 3 (June), pp. 481-53.

Farhi E., Sleet C., Werning I. and Yeltekin S. "Non-linear Capital Taxation Without Commitment." Review of Economic Studies (2012) 79, 1469-1493.

Farhi E. and Werning I., 2008. "The Political Economy of Non-linear Capital Taxation.” Mimeo.

Fournier, J.-M. and J. Lehr, 2018. "Issuing GDP-linked bonds: Supply and demand can match”, OECD Economics Department Working Paper No. 1500.

Grossman H. and Van Huyck J. ,1988. "Sovereign Debt as a Contingent Claim: Excusable Default, Repudiation and Reputation." American Economic Review 78, 1088-97.

International Monetary Fund, 2004, "Sovereign Debt Structure for Crisis Prevention," IMF Occasional Paper No. 237, (Washington).

, 2011, "Managing Volatility in Low-Income Countries-The Role and Potential for Contingent Financial Instruments," IMF Policy Paper, October 31, 2011, (Washington).

, 2016, "Analyzing and Managing Fiscal Risks_-Best Practices," IMF Policy Paper, May 4, 2016, (Washington).

,2017, "State-Contingent Debt Instruments for Sovereigns," IMF Policy Paper, March 23, 2017, (Washington). 
Kehoe, P. and Perri, F. (2002). "Competitive Equilibria with Limited Enforcement." Federal Reserve Bank if Minneapolis working paper 621.

Kim, J., and Ostry, J., 2018, "Boosting Fiscal Space: The Roles of GDP-linked Debt and Longer Maturities," IMF Working Paper No. 18/04.

Kletzer K. and Wright B. (2000). "Sovereign Debt as Intertemporal Barter." The American Economic Review Vol. 90, No.3 (June): 621-39.

Kocherlakota, N. (1996). "Implications of Efficient Risk Sharing Without Commitment."

Makoff, G., 2017, “GDP-indexed Bonds: A Way Forward”, Centre for International Governance Innovation Policy Briefing No. 97.

Marcet A. and Marimon R. (2019). "Recursive Contracts". Econometrica, Volume 87, Issue 5, September 2019, pages 1589-1631.

Neftci, S., and Santos, A., 2003, 'Puttable and Extendible Bonds: Developing Interest Rate Derivatives for Emerging Markets', IMF Working Paper No. 03/201, (Washington: International Monetary Fund).

Ostry, J., Ghosh, A., Kim, J., and Qureshi, M., 2010, “Fiscal Space,” IMF Staff Position Note 10/11, (Washington: International Monetary Fund).

Pienkowski, A., 2017, "Debt Limits and the Structure of Sovereign Debt," mimeograph.

Roch, F. and Roldan, F., 2021. "Uncertainty Premia, Sovereign Default Risk, and StateContingent Debt." IMF Working paper No. 2021/076.

Shiller, R., 1993, "Macro Markets: Creating Institutions for Managing Society's Largest Economic Risks," Oxford University Press.

Summers, L., 2015, "Pandemic Bonds have Potential to be Win-win-win", Financial Times. Available at: http://blogs.ft.com/larry-summers/2015/10/14/pandemic-bonds-havepotential-to-be-win-win-win/.

Wright M. (2001). "Private Capital Flows, Capital Controls and Repudiation Risk." Manuscript, University of Chicago.

Zoheir, E., and Tavakoli, H., 2016, "Countercyclical Financial InstrumentsBuilding Fiscal Resilience to Exogenous Shocks," The Commonwealth Secretariat. 